\title{
VARIÁCIÓ EGY TÉMÁRA - AZ INDONÉZ KÖZTÁRSASÁG REGIONÁLIS VÉDELEMDIPLOMÁCIÁJA MINT REAKCIÓ AZ ÁZSIAI-CSENDES-ÓCEÁNI TÉRSÉG KORTÁRS GEOPOLITIKAI VÁLTOZÁSAIRA
}

\section{VARIATION ON A THEME-REPUBLIC OF INDONESIA'S REGIONAL DEFENCE DIPLOMACY AS A RESPONSE TO CURRENT GEOPOLITICAL CHANGES IN THE ASIA-PACIFIC}

\author{
Szakáli Máté \\ tudományos segédmunkatárs, Pázmány Péter Katolikus Egyetem Bölcsészet- és Társadalomtudományi Kar \\ Modern Kelet-Ázsia Kutatócsoport \\ szakali.mate@btk.ppke.hu
}

ÖSSZEFOGLALÁS

Az Indonéz Köztársaság föbb politikai preferenciái és érdekei különösen a Délkelet-ázsiai Nemzetek Szövetségével (ASEAN), illetve általánosságban a tágabb regionális integrációval szemben is hagyományosan a biztonság és a védelem szakterületeire koncentrálódnak. Ez az ország geostratégiai elhelyezkedésére és történelmi tapasztalataira visszavezethető beállítottság Indonéziát kifejezetten érzékennyé teszi a szuverenitását és területi integritását potenciálisan veszélyeztető geopolitikai fejleményekre, egyúttal ösztönzi Jakartát a regionális biztonsági architektúra aktív fejlesztésére. Ennélfogva jelen tanulmány a részben az ázsiai-csendes-óceáni térségben zajló geopolitikai változásokra reagáló kortárs indonéz védelemdiplomácia főbb ismérveit tekinti át a régió vonatkozásában. Az írás először Indonézia biztonsági kihívásait tipizálja regionális szinten a külső biztonság szempontjából, majd a részben válaszként megfogalmazódott újfajta védelemdiplomácia és "fedezeti stratégia" elméletének lényegét és lokális megvalósulását taglalja. Ezt a közelmúltbeli főbb szakpolitikai tendenciák vizsgálata követi az indonéz stratégiai gondolkodásban és külpolitikai gyakorlatban kulcsfontosságú ASEAN Közösség első pillérére (ASEAN Politikai és Biztonsági Közösség) összpontosítva. A tanulmány amellett érvel, hogy a kül- és védelempolitikai prioritásainak elérése érdekében Jakarta oly módon törekszik megőrizni és maximalizálni stratégiai mozgásterét, hogy az ázsiai-csendes-óceáni térség hatalmi egyensúlyváltozását egy nem zéró összegű játszmaként interpretálja. Ezzel összhangban védelemdiplomáciája eszközként értelmezendő az ország katonai modernizációjának kivitelezéséhez, valamint a regionális hatalmakkal történő szívélyes védelmi kapcsolatok kiépítéséhez. Az elemzés végkövetkeztetése, hogy Indonézia - ugyan erősen behatárolt keretek között, de a geopolitikai változások ellenére - továbbra is a délkelet-ázsiai kormányközi regionális integráció biztonsági dimenziójának legaktívabb állami szereplője, ami a térség stabilitása mellett saját globális ambícióit is szolgálja. 


\begin{abstract}
The main policy preferences and interests of the Republic of Indonesia regarding the Association of Southeast Asian Nations (ASEAN) in particular, and regional integration in general has been related to security and defence. This attitude, derived from the island nation's geostrategic location and historical experiences, has made Indonesia susceptible to geopolitical developments that may threaten her sovereignty and territorial integrity, while activating Jakarta in the development of regional security architecture. This paper examines the background and main drivers of Indonesia's current defence diplomacy formulated to some extent in response to current geopolitical changes in the Asia-Pacific. The study first standardizes the main regional external security challenges the country faces before discussing the theory and localization of the new form of Indonesian defence diplomacy and 'hedging strategy'. This is followed by the examination of recent major policy trends in the first pillar of the ASEAN Community (APSC), a key level to Indonesian strategic thinking and foreign policy practice. In order to achieve her foreign and defence policy priorities, this paper argues, Jakarta seeks to preserve and maximize her strategic leverage in the form of interpreting structural changes in the balance of power of the Asia-Pacific as a non-zero-sum game. Therefore, Indonesia's defence diplomacy can be understood as a means to achieve the country's military modernisation and cordial strategic engagement with powers present in Southeast Asia. The analysis concludes that Indonesia - albeit within a limited framework, yet despite geopolitical changes - has still remained the most active player in the security dimension of her region's intergovernmental integration, serving the purposes of regional stability and her own global ambitions alike.
\end{abstract}

Kulcsszavak: Indonézia, biztonságpolitika, védelemdiplomácia, geopolitika, ASEAN, APBK, integráció, stratégiai érdek, nagyhatalmi versengés

Keywords: Indonesia, security policy, defence diplomacy, geopolitics, ASEAN, APSC, integration, strategic interest, great power rivalry

\title{
BEVEZETÉS - VÁLASZREAKCIÓK A HATALMI EGYENSÚLY VÁLTOZÁSÁRA AZ ÁZSIAI-CSENDES-ÓCEÁNI TÉRSÉGBEN
}

Az ázsiai-csendes-óceáni térség biztonsági, kereskedelmi és gazdasági architektúráját az Amerikai Egyesült Államok „,biztonsági garancia” szerepe övezi, amely a transzregionális stabilitás alapja. Ez a berendezkedés relatíve rugalmasan képes ellenállni többek között a délkelet-ázsiai államok politikai rendszerváltásainak, a Tajvani-szoros periodikus válságainak, az egyes országok között rendszeresen megélénkülő területi konfliktusoknak, az államok változó intenzitású fegyverkezési versenyének, illetve hatalmi rivalizálásának vagy a Koreai-félsziget politikai és katonai kríziseinek. A kortárs nemzetközi rendszer egyik alapvető jellemzője, a globális hatalommegosztás az ázsiai országok javára történő újraformálódása ugyanakkor erodálja a modell stabilitását, és felértékeli a regionális hatalmi 
dinamikákat. A Kínai Népköztársaság (továbbiakban Kína), amely erőforrásai, katonai modernizációja és külpolitikai törekvései révén az Egyesült Államok potenciálisan egyenrangú riválisa, illetve az el nem köteleződés politikájától egyre határozottabban elmozduló, szintén egyre kezdeményezőbb és határozottabb külés biztonságpolitikát folytató Indiai Köztársaság (továbbiakban India) tekinthetők a módosulás elsődleges kiváltóinak. Képességeik és ambícióik mindkét országot legalább saját érdekszférájukban a stratégiai mozgásterük növelésére ösztönzik, ami hozzájárul a status quo érdeminek és tartósnak mutatkozó fokozatos, ám nem egyenletes ütemú újjáalakulásához, amely az általa kiváltott stratégiai dilemmára válaszként megfogalmazott állami taktikák változatosságával párosul.

Ezen kortárs geopolitikai fejlemények tanulmányozásának magyar szakirodalmához jelen tanulmány az Indonéz Köztársaság (továbbiakban Indonézia) - a G20-csoport tagja, a világ legnépesebb muszlim többségú állama, legnagyobb szigetországa és a délkelet-ázsiai kormányközi integráció de facto szektorális vezetője - általános választaktikájának áttekintésével kíván hozzájárulni.

Történelmi perspektívában vizsgálva Indonézia főbb politikai preferenciái és érdekei különösen a Délkelet-ázsiai Nemzetek Szövetségével (ASEAN), illetve általánosságban a tágabb regionális integrációval szemben is hagyományosan a biztonság és a védelem szakterületeire koncentrálódnak. Mégis, a regionális haderő-modernizációk, a megoldatlan határviták, a katonai doktrínák változásai és a külhatalmak Délkelet-Ázsián belüli hatalmi rivalizálásának az ország alapvető stratégiai érdekeit és céljait fenyegető mivolta ellenére a kortárs indonéz politikai döntéshozók nem az ország önvédelmi képességeinek radikális megerősítése vagy egy katonai szövetségkötés kieszközlése, hanem a diplomácia kiemelt biztonsági és védelmi hasznosítása mellett döntöttek. Ennek jegyében Indonézia aktívan törekszik egy biztonsági dimenzióval bíró, szabályalapú regionális kormányközi architektúra felépítésére (úgynevezett ASEAN-centralitás, például az ASEAN Regionális Fórum, az ASEAN+3 vagy a Kelet-Ázsiai Csúcs formájában), továbbá széles körü védelmi és katonai kapcsolatok kiépítésére. Az indonéz hadsereg például rendszeresen folytat személyzeti csere- és közös képzési programokat, valamint koordinált tengeri örjáratokat a szomszédos államokkal. Védelmi beszerzéseibe pedig többek között az Egyesült Államokat, Kínát, Dél-Koreát, Oroszországot, Németországot, Franciaországot és Hollandiát is bevonja.

Ezen ismérvek alapján a tanulmány amellett érvel, hogy az ázsiai-csendesóceáni térség változó hatalmi struktúrájának kontextusában a többoldalú és kétoldalú regionális indonéz védelemdiplomácia az úgynevezett „fedezeti stratégia” alkalmazásaként értelmezhető. Tekintettel geostratégiai elhelyezkedésére és a katonai ereje jelenlegi szintjére, kevésbé valószínü, hogy Indonézia tartósan antagonisztikus pozíciót vegyen fel bármelyik rivalizáló állammal szemben. Ezért az indonéz fedezeti stratégia a partneri elköteleződést és a regionális integrációt 
előmozdító mechanizmusokat egyesíti a realista stílusú egyensúlyozó megközelítéssel, amit a haderőfejlesztés és a stratégiai partnerekkel való biztonsági együttmüködés formájában valósít meg. Azaz az indonéz védelemdiplomácia az ország katonai modernizációjának, illetve a regionális hatalmakkal történő szívélyes védelmi kapcsolatok kialakításának eszközeként értelmezhető, miközben utóbbi interakciókat Jakarta egy, a stratégiai érdekeinek kedvező normákon alapuló biztonsági rendbe törekszik becsatornázni.

Ebben a megközelítésben Indonézia tehát alapvetően egy nem zéró összegü játszmaként igyekszik kezelni a status quo felborulását. Ezen hipotézis igazolására a tanulmány először Indonézia legfőbb regionális biztonsági kihívásait tipizálja, majd a részben válaszként megfogalmazódott újfajta védelemdiplomácia, illetve a fedezeti stratégia megvalósítását mutatja be. Ezt a közelmúltbeli főbb szakpolitikai tendenciák vizsgálata követi az indonéz stratégiai gondolkodás és külpolitikai gyakorlat számára kulcsfontosságú ASEAN szintjén, az integráció első pillérére összpontosítva.

\section{INDONÉZIA REGIONÁLIS SZINTŰ BIZTONSÁGI KIHIVÁSAINAK TÍPUSAI A KÜLSŐ BIZTONSÁG SZEMPONTJÁBÓL}

Indonézia két óceán (az Indiai és a Csendes), illetve két kontinens (Ázsia és Ausztrália) között helyezkedik el; több mint 17 ezer sziget tagolta felségvizein a világkereskedelem és a kommunikáció szempontjából nélkülözhetetlen tengeri útvonalak haladnak át. Geostratégiai jelentősége, valamint számottevő emberi és természeti erőforrásai ellenére Indonézia részben sajátos, részben az egyes feltörekvő országokra egyetemesen jellemző összetett gazdasági és társadalmi problémái, továbbá saját történelmi tapasztalatai következtében kifejezetten érzékeny a szuverenitására és területi integritására, mind a valóság, mind a megjelenés tekintetében. A geopolitikai változásokat ezért az elit komoly nemzetbiztonsági fenyegetésnek észleli, miközben az ország egyre kitettebbé válik egyéb, külső eredetủ biztonsági kihívásoknak is. E tekintetben az ország regionális szintủ külső biztonságát tekintve az indonéz politikai elit aggályai négy típusba csoportosíthatók.

A Kelet-Ázsiában zajló kortárs geopolitikai változások egyik fö eredője a Kínai Népköztársaság gazdasági alapú megerősödése, illetve külpolitikai asszertivitása, továbbá törekvése az Egyesült Államok nyugat-csendes-óceáni térségben meglévő katonai fölényének, gazdasági és politikai befolyásának, illetve jelenlétének minimalizálására, valamint felváltására. Kína ugyanis alapvetően két kulcsfontosságú stratégiai cél érvényesítésére törekszik a térségben: hogy biztosítsa, nincsenek olyan konfliktusai a térséggel, amelyek veszélyeztetnék szuverenitását, területi integritását (a Dél-kínai-tenger vitatott fennhatóságú területe) és 
a nemzetbiztonságát, továbbá annak biztosítása, hogy Délkelet-Ázsia ne kerüljön egy ellenséges hatalom (jelen esetben az USA vagy Japán) érdekszférájába. A regionális hatalmi erőegyensúly relatív strukturális elmozdulása Kína javára ugyanakkor az USA (és Japán) Ázsia-politikájának (hullámzó intenzitású) aktivizálódását is kiváltja, ami Peking és Washington párhuzamos kereskedelmi és gazdasági integrációs kísérleteiben, valamint partnerség- és szövetségépítéseiben is tetten érhető a politika, a diplomácia és a biztonságpolitika területein (Indyk et al., 2012). Ebben a kontextusban tehát Jakarta a térség egyik elsődleges külső biztonsági kihívásának a nagyhatalmi rivalizálást és a Kína megerősödését övező stratégiai bizonytalanságot tartja.

Jóllehet a külső fenyegetések jellegükben nem közvetlen külföldi katonai invázió formájában jelentkeznek, az indonéz politikai vezetésben kiemelt biztonsági aggodalmat keltő jelenség a rohamos katonai modernizációra törekvés és a nemzeti védelmi kiadások - országonként eltérő mértékủ és ütemü, de tendenciózusan - dinamikus növekedése Ázsiában és Óceániában is. A nagyhatalmak délkelet-ázsiai szándékainak gyanakváson alapuló bevett megítélésén túlmenően a térség területi és tengeri határvitái, illetve a határok és az erőforrások biztonsága az ezredfordulót követően szintén kiemelt aggállyá váltak a szigetországban. Ezenfelül a tradicionális és a nem hagyományos biztonsági kihívások közötti egyre összetettebbé váló kapcsolatok is komplikálják Indonézia biztonsági környezetét, például a terrorizmus, a szervezett bünözés, a szeparatizmus vagy a természeti katasztrófák jelenségei nyomán.

\section{A VÉDELEMDIPLOMÁCIA ÉS A FEDEZETI STRATÉGIA ELMÉLETI HÁTTERE, ILLETVE A KORTÁRS INDONÉZ GYAKORLAT}

Egy kormány kül- és biztonságpolitikai céljainak elérése érdekében a kényszer alkalmazása vagy az azzal való fenyegetés hagyományosan bevett eszköz a diplomáciában. A kényszerítő diplomácia apparátusát az indonéz kormányzatok is nyíltan használták érdekeik érvényre juttatásához a függetlenség kikiáltásától (1945. augusztus 17.) kezdve. Például a britek és hollandok elleni katonai múveletek Nyugat-Pápuán, illetve a Maláj Föderációval szemben Sukarno (Soekarno) elnök (1945-1967) antiimperialista külpolitikájának eszközei voltak; Kelet-Timor annektálása pedig Suharto (Soeharto) elnök (1967-1998) antikommunista politikájának és nyugatorientált külpolitikai stratégiájának részét képezte (Gindarsah, 2016).

A védelemdiplomácia fogalmát és gyakorlatát az ókort követően a napóleoni háborúk restaurálták, ám csupán a hidegháború végével létrejövő új globális geopolitikai status quo, a kialakuló új biztonsági szervezetek és interdependenciák biztosítottak teret újfajta alkalmazásának. Általános értelemben véve az újfajta 
védelemdiplomácia lényege az államok átfogóan értelmezett, többdimenziós védelmi érdekeinek képviselete és érvényesítése céljából folytatott diplomáciai tevékenység, amely a katonai képességeket a soft power eszközévé transzformálja. Az elmúlt szük három évtizedben megnőtt az államközi védelmi interakciók ezen új formájának jelentősége, amely magában foglalja a katonai erők és a kapcsolódó infrastruktúrák békeidőben történő együttmüködését a széles körü külpolitikai célok kiszolgálása érdekében (Hills, 2000). Mint viszonylag csekély anyagi ráfordítást igénylö és alacsony kockázatú eszköz a szívélyes védelmi és biztonsági kapcsolatok építésére, a védelemdiplomácia csökkenti a nemzetközi konfliktusok valószínüségét. Délkelet-ázsiai kontextusban, ahol relatíve egyformán gyenge államok eltérő érdekeik szerint követnek különböző politikai logikákat és irányvonalakat, a védelemdiplomácia különös relevanciával és létjogosultsággal bírhat, különösen a nemzetközi kapcsolatokban részt vevő szereplők bővülő körének és intézményesítettségi szintjének fényében.

A fedezeti stratégia olyan állami taktikák sorozataként definiálható, amelyek az olyan beszükült stratégiai döntéshelyzet elkerülését vagy eshetőségeinek tervezését célozzák, amelyben az államok nem képesek egyszerübb politikai alternatívák mellett határozni, mint például az egyensúlyozás, a bandwagoning (az egyensúlyi politikával ellentétes stratégia, amikor egy állam a nála erősebb és vele ellenséges állammal szövetségre lép), a potyautas taktika vagy a semlegesség. Ezek helyett olyan középutas pozíciót kultiválnak, amelyben elejét vehetik a számukra potenciálisan kedvezőtlen status quo kialakulásának (Goh, 2005). Délkelet-ázsiai kontextusban a fedezeti stratégia három eleme azonosítható. Elsőként a közvetett egyensúlyozás, amely elsősorban más nagyhatalmak, különösen az Egyesült Államok meggyőzésére irányul Kína növekvő regionális befolyásának ellensúlyozására. Második eleme Kína politikai, gazdasági és stratégiai szinteken történő összetett és aktív bevonódásának megkövetelése abban a reményben, hogy a kínai vezetők szocializálhatók a jelenlegi nemzetközi szabályoknak és normáknak megfelelő viselkedésre, vagy legalábbis meggyőzhetők azok gyakorlati követéséről (Goh, 2005). Ebben az összefüggésben az indonéz védelemdiplomácia konstruktív fedezeti stratégiaként is értelmezhető, amelyben Jakarta a potenciálisan agresszív kínai uralom ellen és a nagyhatalmi versengés Délkelet-Ázsián kívül tartása érdekében törekszik proaktívan a regionális és szupraregionális biztonsági együttműködések elősegítésére. A harmadik elem egy általános „behálózó” politika, amely a térség hatalmainak érdekeltségét egy stabil regionális rend fenntartásában az abba való partneri és konstruktív bevonásukkal igyekszik elérni.

A védelemdiplomáciát az indonéz vezetés az ezredfordulón adaptálta explicit szakpolitikai irányként, amikor a 2002-es védelmi stratégiában a diplomácia „az első védelmi vonalként" (BPPI, 2002, 37.) került meghatározásra, a konfliktusmegelőzés egyik legfontosabb eszközeként ismerve el azt. Ezen logika keretében az indonéz védelemdiplomácia három kulcsfontosságú programra összpontosít: 
a bizalomépítésre, a katonai képességek kiaknázására és a hazai védelmi ipari bázisok fejlesztésére. A legutóbbi, 2016-os védelmi fehér könyv már a következő megállapításokat tartalmazza:

- „a nemzetvédelemhez kapcsolódó és az azt érintő problémák megoldása érdekében Indonéziának elsőbbséget kell biztosítania a modern katonai erő által támogatott diplomáciának [...] Indonézia aktívan ösztönzi a globális partnerségeket, elősegíti az összetartozás szellemét, és dinamikus egyensúlyt teremt, amely állapotot az egy régión belüli domináns államhatalom hiánya jellemzi. A bizalmon alapulva ez a megnövekedett együttmüködés és partnerség lehetőséget teremt a nemzet védelmi erejének növelésére" (BPPI, 2016, 2.).

- „A nemzetközi együttmüködés a védelemdiplomácia eszköze [...] a nemzetközi együttmúködés a védelem terén a regionális biztonság és stabilitás megteremtésének egyik hídjaként szolgál.” (BPPI, 2016, 78.)

- „A kétoldalú együttmüködés a védelem területén a védelemdiplomácia megvalósítását célozza. A megvalósítás továbbfejleszti a bizalomépítést, és a békés megoldások megtalálását a biztonsági kérdések kezelésére.” (BPPI, 2016, 78.)

A fehér könyv ezen megállapításai összhangban vannak a regionális védelmi kihívások indonéz szempontból történő fenti csoportosításával és priorizálásával. Az elsőként rangsorolt külső, regionális szintủ kihívás, a nagyhatalmi rivalizálás és az általa kiváltott stratégiai bizonytalanság szemszögéből három nemkívánatos stratégiai szcenárió azonosítható, melyek valószínűségének minimalizálására, mint a fedezeti stratégia a védelemdiplomácia keretében történő alkalmazásának fő indokára tekinthetünk. Ez a három eshetőség a kínai uralom vagy hegemónia létrejötte a délkelet-ázsiai régióban, az amerikai kivonulás a térségböl, valamint egy alapvetően és tartósan instabil regionális rend kialakulása.

Az indonéz regionális stratégiai szemlélet átfogó koncepcionalizálását az alábbiakban az indonéz védelemdiplomácia és fedezeti stratégia mint szakpolitika gyakorlati alkalmazásának vizsgálata követi áttekintő komparatív politikaelemzés keretében.

\section{AZ INDONÉZ VÉDELEMDIPLOMÁCIA ÉS FEDEZETI STRATÉGIA MEGVALÓSULÁSA A REGIONÁLIS INTEGRÁCIÓ BIZTONSÁGI PILLÉRÉBEN (ASEAN POLITIKAI-BIZTONSÁGI KÖZÖSSÉG, APBK) AZ EZREDFORDULÓ UTÁN}

Délkelet-Ázsia 1967 óta tartó államközi békéjében az ASEAN mint biztonsági dimenzióval bíró kormányközi szervezet legfőbb érdemének nem a konfliktusmegelőző vagy a konfliktusmegoldó képessége tekintendő, hanem az, hogy képes 
megakadályozni a konfliktusok nyílt háborúvá eszkalálódását. Ebben az összefüggésben Indonézia kezdeményező, aktív és konstruktív szerepet tölt be, amit az indonéz politikai elit körében elterjedt azon - a szakpolitikai retorikában és gyakorlatban is kifejezésre jutó, illetve kormányváltásokat túlélő - meggyőződés tesz lehetővé, miszerint az ASEAN-nak Délkelet-Ázsia regionális biztonsági architektúrája középpontjában kell állnia. Erre Jakarta álláspontja szerint azért van szükség, hogy a szervezet mérsékelni tudja a külső szereplők régión belüli befolyását, és lehetővé tegye a regionális biztonsági kihívások lokális vezetésủ megoldásainak kidolgozását, illetve érvényesítését. Az összes regionális biztonsági kihívás komplexitása mellett tehát az indonéz stratégiai gondolkodásban a feszültségek csökkentésére és a fegyveres konfliktusok elkerülésére a legideálisabb megoldásnak a normákon alapuló regionális biztonsági rend kialakítása tetszik. Ennek érdekében Jakarta elősegíti az ázsiai-csendes-óceáni térség országainak jövőbeni magatartására vonatkozó, általa (is) preferált alapelvek, például az erőszakmentesség, az átláthatóság és a bizalomépítés elterjedését és alkalmazását, ami funkcionálisan egyfajta „dinamikus egyensúlyt” létesíthetne a délkelet-ázsiai szubrégió államai és a külhatalmak között (Natalegawa, 2011). A regionális kohézió eme egyetemes erősítését az indonéz védelemdiplomácia a nagyhatalmi kapcsolatok békés és jóindulatú kezelésével párhuzamosan végzi.

Mindazonáltal az indonéz védelemdiplomácia keretében alkalmazott fedezeti stratégia a partneri elköteleződést és a regionális integrációt előmozdító mechanizmusokat az ország katonai modernizációjára való törekvéssel párosítja. Az indonéz kormányok többoldalú kötelezettségvállalásaikon kívül ugyanis folyamatos katonai modernizációt hajtanak végre, hogy megőrizzék az ország standard elrettentőképességét (Natalegawa, 2011). A modernizációs folyamatot az úgynevezett „minimális alapvető készség” (MAK) elérésének koncepciója keretezi. A koncepció célja olyan képességalapú védelmi és erőszint elérése három fázis során, amely garantálja az azonnali stratégiai érdekvédelmet, és amelyben beszerzési prioritást élvez a minimális védelmi erő javítása és/vagy az elavult főbb fegyverrendszerek/berendezések cseréje (URL2). Ezen túlmenően a magasabb szintủ fegyvergyártói önellátása érdekében Jakarta arra törekszik, hogy védelmi ipari partnerség révén megújítsa stratégiai iparágának képességeit is (Gindarsah, 2016, 7.). A fegyverbeszerzések fentebb említett diverzifikáltsága is az egyensúlyozás-orientált védelempolitika jele, mivel a fedezeti stratégia a diplomácia és a katonai modernizáció komplementaritása és relatív tág fókusza miatt Indonézia többoldalú és kétoldalú védelmi relációit is áthatja.

A bevezetőben felvázolt hipotézis igazolásához az ASEAN Politikai és Biztonsági Közösség (APBK) tekintetében elvégzett, a főbb közelmúltbeli eseményekből kirajzolódó tendenciákra összpontosító komparatív politikaelemzésre is szükség van, hogy következtetni lehessen Indonézia hozzájárulásának a fehér könyvekben deklarálton túli valós módjára és mértékére a regionális biztonsági 
integrációt illetően. Az analitikai megközelítéssel első lépésben azt törekszünk felderíteni, hogy Indonézia jelenleg milyen szerepet vállal a biztonsági integrációban; a második lépésben pedig azt próbáljuk felmérni, hogy az ország maga milyen egyoldalú lépéseket tesz.

\section{INDONÉZIA SZEREPVÁLLALÁSA AZ ASEAN BIZTONSÁGI INTEGRÁCIÓJÁNAK AZ EZREDFORDULÓ UTÁNI EVOLÚCIÓJÁBAN}

A Délkelet-ázsiai Nemzetek Szövetségére sajátos müködési metódus, az úgynevezett ASEAN-mód jellemzö, amely a délkelet-ázsiai kulturális normákat tiszteletben tartó informális, illetve személyes kormányközi munka- és döntéshozatali metodológiát foglalja magában. Ennek során a politikai döntéshozók minden esetben a kompromisszum, a konszenzus és a konzultáció eszközeire, valamint a csendes diplomáciára támaszkodnak. Az ASEAN vezetői ekképpen a tagállami nyilvánosságok kizárásával kommunikálhatnak, ami mérsékli a konfrontációk kialakulásának és növeli a közmegegyezésre jutás sikerességének esélyét (Masilamani-Peterson, 2014). Az ASEAN-mód következtében ugyanakkor az egyes tagállamok szerepvállalására a regionális integráció evolúciójának alakításában elsősorban az esetleges kezdeményezéseik és az ASEAN-csúcstalálkozók végeredményei alapján következtethetünk. Az integráció biztonsági dimenziója megfogalmazásában, illetve kialakításában mindazonáltal Indonéziának egyértelmüen központi szerep tulajdonítható, például a Béke, a Szabadság és a Semlegesség Zónája (ZOPFAN), a Délkelet-ázsiai Atomfegyvermentes Zóna (SEANWFZ), illetve maga az APBK létrejötte folytán (Heiduk, 2016, 11.).

A délkelet-ázsiai biztonsági közösség fejlesztésének ötletei az APBK formájában a Bali Concord II (2003) részeként manifesztálódtak. Az APBK konceptualizálása pedig jórészt az indonéz külügyminisztériumhoz köthetö Indonézia 2003-as soros ASEAN elnöksége idején. A Bali Concord II feladatkijelölése alapján Jakarta állította össze a pillér létrejöttéhez szükséges intézkedések listáját is, amely többek között egy ASEAN békefenntartó erő és egy regionális terrorizmusellenes központ létrehozására, illetve a tagállamok közötti katonai együttmüködések aseanizációjára tett javaslatot (Sukma, 2011). Az indonéz előterjesztések ilyetén módon a regionális intézményi kapacitások továbbfejlesztésére és megerősítésére irányultak a konfliktuskezelés területén, egyúttal a délkelet-ázsiai államok egymás közti kapcsolataiban sérthetetlennek tartott be nem avatkozás elvének fokozatos puhítását célozták, különösen az olyan fejlemények esetére, amikor az egyik tagállam belső biztonsági eseményei destabilizáló hatást gyakorolhatnak a szomszédos államokra. Más tagországok erősen ellenezték az intézkedéstervezeteket, ezáltal Indonézia paradigmaváltó és/vagy határozott intézményesítést célzó kezdeményezéseinek többsége elutasításra került. Az egyetlen, 
kötelező érvényü regionális megnemtámadási szerződés megkötésére vonatkozó indonéz próbálkozás sem ért célt, a minden döntéshozatal során a legkisebb közös érdek érvényesülését elősegítő ASEAN-mód következtében (Emmers, 2014).

Ezzel együtt vannak elfogadásra került és eredményesnek bizonyuló indonéz biztonsági aspektusú kezdeményezések. Az ASEAN Alapokmány (2007) megfogalmazása például javarészt a szigetország érdeme, ez sikeresen foglalta az okmányba a demokrácia és az emberi jogok iránti normatív elkötelezettséget. Az ASEAN Kormányközi Emberi Jogi Bizottság megalakulásában (2009) és a régió mintegy 600 millió lakosát érintő ASEAN Emberi Jogi Nyilatkozat kiadásában (2012) Jakarta szintén instrumentális szerepet játszott. A 2002. évi bali robbantásokat követően pedig a szigetország vállalta magára (Malajzia és a Fülöp-szigetek mellett) a terrorizmusellenes tagállami erőfeszítések aktív regionalizálását, ami például a terrorizmus egységes délkelet-ázsiai meghatározását, valamint a volt terroristák rehabilitációjára és reintegrációjára vonatkozó irányelveket is tartalmazó ASEAN Terrorizmusellenes Egyezményben (2007) érhető tetten. Az egyezmény utóbbi eleme példázza, ahogy Indonézia sikeresen ágyazta be regionális szintre a saját biztonságpolitikai preferenciáit tükröző soft power megközelítését, miközben el is választotta magát és az ASEAN-t a terrorizmusellenes politika az Egyesült Államokra és Kínára jellemző militarizálásától (Natalegawa, 2013b).

Jakarta - fenti példákkal is felvázolt - törekvése, hogy a regionális konfliktuskezelés szellemi vezetőjeként müködjön, az indonéz vezetők konszenzusos, kormányváltásokat túlélő meggyőződésén alapul: eszerint a regionális biztonság és stabilitás a nemzeti fejlődés és jólét előfeltétele, illetve az indonéz hatalmi ambíciók alapja. Szintén bevett nézet az indonéz politikai elit köreiben, hogy amenynyiben az ASEAN meg kívánja őrizni létjogosultságát és funkcionalitását a geopolitikai változások és az újonnan felmerülő biztonsági kihívások dacára, akkor növelnie kell intézményesítettségi szintjét a biztonság és a védelem terén. Erre a vélekedésre vezethető vissza, hogy Jakarta egy, a külországok befolyásától a lehetö legnagyobb mértékben független, ASEAN-vezetésủ regionális biztonsági architektúrát preferál nyíltan és tevőlegesen a külországokkal fenntartott kétoldalú katonai szövetségeken alapuló biztonsági architektúrával szemben. Ezen logika mentén az ASEAN-központú délkelet-ázsiai biztonsági rendszer a többi térségbeli mechanizmus és fórum irányításába való bekapcsolódást is megalapozhatja.

Az indonéz regionalizmusmegközelítés következésképpen eltér más ASEANtagországok, például Thaiföld, a Fülöp-szigetek, Vietnam és Szingapúr álláspontjától, amelyek saját nemzetbiztonsági politikájukat az Egyesült Államokkal fenntartott biztonsági szövetségeik keretében alakítják; vagy a védelmi kérdésekben jobbára Kína-orientált Mianmar/Burma, Kambodzsa és Laosz taktikáitól. Az indonéz regionális ambíciókban ugyanis, érvelhetünk, tetten érhető az ország védelemdiplomáciájának és fedezeti stratégiájának cél- és eszközrendszere. Ennek következtében pedig Indonézia döntő szerepet játszott az ASEAN Közösség első 
pillérének létrejöttében, illetve kulcsszerepet játszik annak fejlesztésében ötletek és szakpolitikai koncepciók biztosításával, valamint a napirend és a multilaterális dialógus témáinak navigálásával. Az a tény azonban, hogy a regionális biztonsági integráció elmélyítésére irányuló indonéz kezdeményezéseket ritkán sikerül elfogadtatni és megvalósítani, vitát vált ki a szigetországon belül az ASEAN reformjának és továbbfejlesztésének lehetőségeiről, illetve az indonéz elit meggyőződéseinek és az ország azt tükröző stratégiai doktrínájának relevanciájáról.

\section{INDONÉZIA SAJÁT REGIONÁLIS KEZDEMÉNYEZÉSEINEK EGYOLDALÚ FOGANATOSÍTÁSA}

Noha a szövetség az egyes tagállamok érdekvédelmének kedvezö, érdekérvényesítésének azonban kedvezötlen döntéshozatali mechanizmusa következtében Jakarta ritkán tudja elfogadtatni az integrációt szorosabb, mélyebb, hatékonyabb biztonsági közösséggé formáló elképzeléseit a többi délkelet-ázsiai kormánnyal, egyoldalúan számos intézkedést hajt végre, ahogy azt az alábbi három példa is illusztrálja.

Amikor az évszázados thai-kambodzsai határvita a Preah Vihear templom körüli területről 2011 februárjában az ASEAN megalakulása (1967) óta példátlan fegyveres harcokká eszkalálódott a két ország fegyveres alakulatai között, Jakarta lépett fel közvetítőként. Indonézia az ASEAN soros elnökeként rendkívüli külügyminiszteri ülést hívott össze, amelyen Bangkok és Phnom Penh elköteleződést mutattak a párbeszéd iránt. A magas szintủ informális tárgyalások májusra tartós tủzszüneti megállapodáshoz és a vitatott hovatartozású terület demilitarizálásához vezettek, amelyek betartását a felek a határ mindkét oldalán indonéz megfigyelő egységekre bízták (Vatikiotis, 2011). Az eset rámutat, hogy ugyan egy ASEAN békefenntartó erő létrehozásának indonéz koncepcióját a többi tagállam elvetette, Jakarta egyoldalúan mégis végrehajtott számos intézkedést a konfliktusmegelőzés és a konfliktuskezelés területein. Jelen esetben aktívan demonstrálta sikeres közvetítői müködését egy államközi fegyveres konfrontáció során, illetve felhívta a figyelmet a Délkelet-ázsiai Barátsági és Együttmüködési Szerződés (1976) betartásának fontosságára.

A 2012. júliusi ASEAN-csúcstalálkozót követően Indonézia szintén diplomáciai közvetítő szerepet vállalt, miután a szövetség történetében elöször a tagállamok képtelennek bizonyultak megállapodni egy közös zárónyilatkozat kiadásáról. A sikertelenség oka a dél-kínai-tengeri területi vitában érdekelt felek eltérö álláspontja volt: a Kína-párti kambodzsai kormány nem volt hajlandó a nyilatkozat részeként elfogadni Vietnam és a Fülöp-szigetek szerinte nyíltan Kína-kritikus álláspontját. Indonézia aktív diplomáciai erőfeszítései kulcsfontosságú szerepet játszottak a megegyezésképtelenség okozta presztízsveszteség minimalizálásában, illetve a konszenzusteremtésben egy utólagos nyilatkozat körül. Ennek előzménye az indonéz külügyminiszter által kezdeményezett és vezetett konzultáció volt a fe- 
lek között, amelyen megállapodás született az ASEAN hat pontból álló elveiröl a Dél-kínai-tengert illetően: ezek alapvetően a felek korábbi többoldalú politikai szándéknyilatkozatainak, a releváns nemzetközi tengerjog rendelkezéseinek és az erőszaktól tartózkodó fellépés elvének rögzítését foglalják magukban (URL1).

Az államközi és multilaterális eseti közvetítések mellett Indonézia aktívan vesz részt államon belüli konfliktusok megoldásában is: például tevékeny szerepet játszott a filippínó központi kormányzat és a muszlim többségű Mindanao függetlenségéért harcoló Moro Nemzeti Felszabadítási Front (MNFF) közötti béketárgyalásokban. Az Iszlám Konferencia Szervezete bizottságainak elnökeként Jakarta évtizedeken át támogatta a békefolyamatot konzultációs találkozók szervezésével a manilai kormány és az MNFF között és az MNFF-fel folytatott tárgyalások Nemzetközi Monitoring Csoportjában való részvétellel; továbbá a fegyveres konfliktusnak hivatalosan a Jakarta által közvetített egyetértési megállapodás aláírása vetett véget 2010-ben (Hernández, 2014, 159.).

A többek között a konfliktusmegelőzést és a konfliktuskezelést célzó indonéz biztonsági kezdeményezések egyoldalú foganatosítása a regionális szintű intézményesítésük kudarca esetén egyszerre illusztrálja az indonéz védelemdiplomácia motiváltságát és ambícióit, illetve annak korlátait. Jakarta szintén fontos szerepet játszott az ASEAN Béketeremtési és Megbékélési Intézetének (ABMI) létrehozásában, amelynek célja az államon belüli és az államok közötti konfliktusok békés megközelítésének és megoldásának elömozdítása a regionális szintủ szellemi kapacitásbővítés révén (Natalegawa, 2013a). Indonézia eredeti elképzeléseivel ellentétben azonban az ABMI független ellenőrzési hatáskörrel nem rendelkező, finanszírozásában föként önkéntes hozzájárulásokra támaszkodó, alacsonyabb egyeztetési szintü intézmény.

\section{ÖSSZEGZÉS}

A kortárs változások az ázsiai-csendes-óceáni térség hatalomstruktúrájában folyamatos stratégiai kihívást jelentenek a nemzetállami és regionális biztonsági architektúrák számára. Az ASEAN tagállamok részben az egymás közötti együttmüködésük relatív mélyítésével reagáltak a kihívásra; míg a szövetség pozícióját a tágabb regionális biztonsági szerkezet központjaként a külhatalmaknak a szervezetre épülő multilaterális intézményekbe ágyazásával sikerült megőrizniük. Ilyen intézmények az ASEAN Regionális Fórum, az ASEAN+8, a Kelet-Ázsia Csúcstalálkozó vagy az ASEAN Védelmi Miniszteri Találkozó Plusz.

Indonézia fö politikai preferenciái és érdekei általánosságban az ASEAN-nal és különösen a regionális integrációval szemben történelmileg a biztonság és a védelem területén helyezkedtek el. A tanulmány arra törekedett rámutatni, hogy ez a beállítottság a geopolitikai változások dacára a mai napig fennáll, mivel Ja- 
karta az intézményesített, normaalapú regionális biztonsági együttműködést tekinti a legmegfelelöbb eszköznek a stratégiai bizonytalanságok enyhítésére. Noha az ország nincs abban a helyzetben, hogy a nagyhatalmi relációk stratégiai irányát meghatározhassa, saját stratégiai autonómiájának fenntartására változatlanul és aktívan törekszik; ezáltal pedig Délkelet-Ázsia autonómiájának és biztonságának maximalizálását is előmozdítja egyfajta nemzetközi közjó formájában.

A biztonsági kihívásokra adott indonéz reakciók az ország számára negatív hatások minimalizálását célzó fedezeti stratégia elméleti keretében kiválóan értelmezhetővé válnak. A fedezeti stratégia érvényesítése ezen megközelítésben áthatja Indonézia többoldalú és kétoldalú regionális védelemdiplomáciájának realizálását és kilátásait is. Kelet-Ázsia változó hatalmi struktúrájának fényében Indonézia védelemdiplomáciája a regionális integráció, a katonai modernizáció és a partneri kapcsolatok kiépítését szolgáló mechanizmusokat egyesíti a realista szemléletű egyensúlyi megközelítéssel. Ennek alapvető célja egy olyan stratégiai döntéshozatali szituáció elkerülése, amelyben Jakarta egy, a saját stratégiai mozgásterét beszükítő nagyhatalmi szövetségkötésre kényszerülne. Ez alapján pedig megállapítható, hogy kül- és védelempolitikai prioritásainak elérése érdekében Jakarta oly módon törekszik megőrizni és maximalizálni a stratégiai lehetőségeinek körét, hogy a hatalmi struktúraváltozást zéró összegü helyett egy nem zéró összegü játszmaként interpretálja. Ennek keretében Indonézia instrumentális szerepet játszik a regionális biztonsági integráció fejlesztésében, és ezzel összhangban a témakijelölő, közvetítő és problémamegoldó beavatkozásai mellett akár egyoldalúan is végrehajtja a vonatkozó biztonsági javaslatait. Az ASEAN-mód ellenére ugyanakkor a beavatkozások mellett az APBK-ban egyértelmúen Indonéziának tulajdonítható a vezető (normatív) szerep, a proaktív diplomáciai tevékenység, a reformötletek kidolgozása, a napirend menedzselése és az integrációs irány határozottabb kijelölése. Ez az indonéz politikai elit nagy részének azon szemléletére is visszavezethető, hogy fejlődése és jóléte mellett Indonézia globális státuszát és befolyását szorosan kötődőnek tételezik az ASEAN de facto regionális vezetőjeként betöltött státuszához. Ezen elképzelés mindenkori megvalósíthatóságát mindazonáltal árnyalja, hogy az indonéz védelemdiplomácia, annak taktikája és stratégiai irányultsága végső soron nagymértékben a nagyhatalmi kapcsolatok evolúciójának függvénye.

\section{IRODALOM}

BPPI - Buku Putih Pertahanan Indonesia (2002): (Indonéz Fehér Könyv. Jakarta: Védelmi Minisztérium)

BPPI - Buku Putih Pertahanan Indonesia (2016): (Indonéz Fehér Könyv. Jakarta: Védelmi Minisztérium) 
Emmers, R. (2014): Indonesia's Role in ASEAN: A Case of Incomplete and Sectorial Leadership. The Pacific Review, 27:4, 543-562. DOI: 10.1080/09512748.2014.924230

Gindarsah, I. (2016): Strategic Hedging in Indonesia's Defense Diplomacy. Defense \& Security Analysis, 32, 4, 336-353. DOI: 10.1080/14751798.2016.1233695

Goh, E. (2005): Meeting the China Challenge: The US in Southeast Asian Regional Security Strategies. (Policy Studies No. 16.) Washington: East-West Center Washington, http://citeseerx.ist. psu.edu/viewdoc/download?doi=10.1.1.554.1497\&rep=rep1\&type=pdf

Heiduk, F. (2016): Indonesia in ASEAN Regional Leadership between Ambition and Ambiguity. (Stiftung Wissenschaft und Politik Paper) Berlin: Stiftung Wissenschaft und Politik, https:// www.swp-berlin.org/fileadmin/contents/products/research_papers/2016RP06_hdk.pdf

Hernández, A. (2014): Nation-Building and Identity Conflicts. Facilitating the Mediation Process in Southern Philippines. Berlin: Springer DOI: 10.1007/978-3-658-05215-7, https://www. researchgate.net/publication/261222901_Nation-building_and_Identity_Conflicts_Facilitating_the_Mediation_Process_in_Southern_Philippines

Hills, A. (2000): Defense Diplomacy and Security Sector Reform. Contemporary Security Policy, 21, 1, 46-67. DOI: 10.1080/13523260008404244

Indyk, M. - Lieberthal, K.- O'Hanlon, M. (2012): Scoring Obama's Foreign Policy: A Progressive Pragmatist Tries to Bend History. Foreign Affairs, 91, 3, 29-43. https://www.foreignaffairs. com/articles/2012-04-20/scoring-obamas-foreign-policy

Masilamani, L. - Peterson, J. (2014): The "ASEAN Way": The Structural Underpinnings of Constructive Engagement. Foreign Policy Journal weboldala, https://www.foreignpolicyjournal. com/wp-content/uploads/2014/10/141015-Masilamani-Peterson-ASEAN.pdf

Natalegawa, M. M. (2011): Annual Press Statement of Foreign Minister of the Republic of Indonesia. Jakarta: Ministry of Foreign Affairs, https://www.kemlu.go.id/sanfrancisco/id/ arsip/pidato/Pages/ANNUAL-PRESS-STATEMENT-OF-THE-FOREIGN-MINISTER-OFTHE-REPUBLIC-OF-INDONESIA-DR.-R.M.-MARTY-M.-NATALE.aspx

Natalegawa, M. M. (2013a): Opening Address by H.E. R.M. Marty M. Natalegawa Minister for Foreign Affairs Republic of Indonesia at the $2^{\text {nd }} A S E A N-U N$ Workshop on Conflict Prevention and Preventive Diplomacy. ASEAN, http://asean.org/?static_post=opening-address-by-he-rmmarty-m-natalegawa-minister-for-foreign-affairs-republic-of-indonesia-at-the-2nd-asean-unworkshop-on-conflict-prevention-and-preventive-diplomacy-2

Natalegawa, M. M. (2013b): Statement by H.E. Mr. R.M. Marty M. Natalegawa, Minister for Foreign Affairs of the Republic of Indonesia, Session I-Opening Session: Strengthening the Implementation of the United Nations Global Counter Terrorism Strategy. http://www.un.org/ en/terrorism/ctitf/pdfs/opening-session-stmt-Indonesia.pdf

Sukma, R. (2011): Do New Democracies Support Democracy? Indonesia Finds a New Voice. Journal of Democracy, 22, 4, 110-123. (114). DOI: 10.1353/jod.2011.0057

Vatikiotis, M. (2011): Indonesia Ends Its Turn at the Helm with a Stronger and More Secure ASEAN. The Jakarta Globe, http://www2.irrawaddy.com/article.php?art_id=22498

URL1: Statement of ASEAN Foreign Ministers on ASEAN's Six-Point Principles on the South China Sea. (2012): ASEAN, a szervezet weboldala, http://www.asean.org/storage/images/ AFMs\%20Statement\%20on\%206\%20Principles\%20on\%20SCS.pdf

URL2: Peraturan Presiden Republik Indonesia Tentang Kebijakan Umum Pertahanan Negara. (2008). Indonéz Pénzügyminisztérium weboldala, https://jdih.kemenkeu.go.id/fulltext/2008/ 7TAHUN2008PERPRES.htm 